\title{
IMPLEMENTASI KEGIATAN MUHADHOROH DALAM MENUMBUHKAN LIFE SKILL SISWA SMK MUHAMMADIYAH 2 GRESIK
}

\author{
Dimas Afrizal \\ Aslich Maulana \\ Universitas Muhammadiyah Gresik
}

\begin{abstract}
Abstrak
Implementasi Kegiatan Muhadhoroh dalam Menumbuhkan Life Skill Siswa SMK Muhammadiyah 2 Gresik. Skripsi Jurusan Pendidikan Agama Islam, Fakultas Agama Islam, Universitas Muhammadiyah Gresik.Tujuan dari penelitian ini adalah untuk mengetahui implementasi kegiatan muhadhoroh dalam menumbuhkan life skill siswa SMK Muhammadiyah 2 Gresik serta faktor pendukung dan penghambat kegiatan muhadhoroh dalam menumbuhkan life skill siswa di sekolah tersebut.Penelitian ini menggunakan pendekatan kualitatif. Data yang diperoleh dalam penelitian ini melalui observasi, wawancara, dan studi dokumentasi. Dan berdasarkan data yang diperoleh tersebut peneliti analisis menggunakan analisis deskriptif, yaitu dengan mendeskripsikan atau menggambarkan apa adanya hasiltemuan di lapangan terkait implementasi kegiatan muhadhoroh dalam menumbuhkan life skill siswa SMK Muhammadiyah 2 Gresik. Hasil penelitian ini menunjukkan bahwa SMK Muhammadiyah 2 Gresik telah melaksanakan kegiatan muhadhoroh sebagai bentuk kegiatan khusus yang diselenggarakan oleh SMK Muhammadiyah 2 Gresik. Berdasarkan hasil penelitian di lapangan, peneliti memperoleh beberapa temuan antara lain kegiatan muuhadhoroh rutin dilaksanakan setiap hari jumat pukul 07.00 wib sampai selesai, kegiatan muhadhoroh wajib dilaksanakan oleh setiap perwakilan masing-masing kelas yang telah terjadwal. Selain itu banyak manfaat bagi siswa setelah mengikuti kegiatan muhadhoroh tersebut yakni semakin memiliki skill serta kepercayaan diri dalam berbicara di depan pubik. Namun pada saat pelaksaannya masih terdapat permasalah internal dari beberapa siswa, mulai dari kurangnnya rasa tanggung jawab dari siswa yang ditunjuk sebagai petugas serta adanya siswa yang ramai saat kegiatan muhadhoroh berlangsung. Kegiatan muhadhoroh di SMK Muhammadiyah 2 Gresik dirasa sudah cukup baik melihat latar belakang sekolah tersebut merupakan sekolah kejuruan dan bukan pondok pesantren.
\end{abstract}

Kata Kunci: implementasi, muhadhoroh, life skill 


\section{PENDAHULUAN}

I

slam merupakan agama dakwah, oleh

karena Islam harus disebarkan kepada seluruh umat manusia. Dengan demi-kian umat Islam bukan hanya berkewajiban melaksanakan ajaran Islam dalam kehidu-pannya, melainkan mereka juga harus mendakwahkan kebenaran ajaran Islam terhadap orang lain. ${ }^{1}$ Strategi dakwah umat Islam bukan hanya melalui syiar dengan khotbah saja melainkan juga memalui berbagai media seperti media cetak, visual maupun elektronik. Namun dari sekian banyak media serta metode yang digunakan, dakwah secara lisan tentunya masih sangat layak digunakan dalam berdakwah karena di dalam dakwah secara lisan dapat terjadi interaksi antara pembicara dengan audiens.

Salah satu metode dakwah lisan adalah dengan melaksanan kegiatan Muhadhoroh. Muhadhoroh merupakan suatu rangkaian kegiatan atau proses, dalam rangka mencapai satu tujuan tertentu. Tujuan ini dimaksudkan untuk memberi arah atau pedoman bagi gerak kegiatan dakwah. Sebab tanpa tujuan yang jelas seluruh ativitas dakwah akan sia-sia. ${ }^{2}$

Berdakwah merupakan kewajiban bagi setiap umat muslim di seluruh dunia guna terus membagikan kebaikan serta kebenaran agama Islam. Kewajiban berdakwah bukan hanya bagi orang-orang yang telah dewasa (baligh) namun siapa pun wajib untuk berdakwah dengan catatan memiliki ilmu serta mengetahui kebenaran dari apa yang ia dakwahkan.

\section{Rumusan Masalah}

Rumusan masalah yang diperoleh dari latar belakang masalah diatas adalah sebagai berikut:

1. Bagaimana implementasi kegiatan muhadhoroh dalam menumbuhkan life skill siswa SMK Muhammadiyah 2 Gresik?

2. Apa saja faktor pendukung serta faktor penghambat kegiatan muhadhoroh di SMK Muhammadiyah 2 Gresik?

\section{Tujuan Penelitian}

Adapun tujuan dari penelitian ini adalah sebagai berikut:

1. Untuk mengetahui implementasi kegiatan muhadhoroh dalam menumbuhkan life skill siswa SMK Muhammadiyah 2 Gresik.

2. Untuk mengetahui faktor pendorong dan faktor penghambat kegiatan muhadhoroh di SMK Muhammadiyah 2 Gresik.

\section{Fokus Peneltian}

Fokus penelitian dalam penelitian ini adalah terfokus pada kegiatan muhadhoroh yang dilaksanakan oleh siswa kelas X (APK dan DKV) dan kelas XII (APK dan DKV) di SMK Muhammadiyah 2 Gresik.

\section{Manfaat Penelitian}

Hasil penelitian ini diharapkan dapat memberi manfaat sebagai berikut:

1. Manfaat Teoritis. Dengan adanya penelitian ini diharapkan mampu menambah taraf keilmuan bagi setiap 
pembacanya serta mengenai kegiatan muhadhoroh dalam menumbuhkan life skill siswa.

2. Manfaat Praktis. Manfaat praktis dari penelian ini diharapkan mampu memberikan rujukan bagi pejuang pendidikan, khususnya pendidikan islam dalam menerapkan kegiatan muhadhoroh di dunia pendidikan untuk menumbuhkan life skill bagi para peserta didik sebagai bekal di kehidupan bermasyarakat.

\section{TINJAUAN PUSTAKA}

Penelitian sebelumnya adalah hasilhasil penelitian yang telah dilaksanakan terlebih dahulu yang akan djadikan sebagai landasan untuk penelitian. ${ }^{3}$ Setelah dilakukan pencarian, peneliti menemukan beberapa hasil penelitian yang telah dilaksanakan. Diantara penelitian terdahulu tersebut adalah sebagai berikut:

1. Fima Riska Oktari, mahasiswi UIN Raden Intan Lampung, NPM 1341010065, pada tahun 2017 dengan judul skripsi "Strategi Pelatihan Muhadharah Terhadap Kemampuan Berpidato Santri Pondok Pesantren Darul Falah Teluk

Betung Bandar Lampung”. Skripsi ini meneliti tentang strategi pelatihan muhadharah terhadap kemampuan berpidato santri di pondok pesantren Darul Falah Teluk Betung Bandar Lampung. Dan hasil dari penelitian tersebut adalah metode yang digunakan Pondok Pesantren darul Falah dalam kegiatan muhadharah ini adalah metode ceramah dengan menuntut santrinya satu persatu tampil di depan umum serta mene- rapkan metode kontinyu dengan melatih santrinya terus menerus berbicara didepan bukan hanya untuk berceramah namun juga untuk menjadi MC. Strategi muhadharah yakni kegiatan yang dilaksanakan pengurus dengan membuata daftar nama kelompok, lalu membuatkan jadwal muhadharah, sebelum tampil siswa diwajibkan membuat teks pidato untuk dikoreksi oleh pengurus agar santri tidak ragu dalam menyampaikannya di depan umum. ${ }^{4}$

2. Dian Faishal Rahman, mahasiswa IAIN Salatiga, NPM 11111220, pada tahun 2016 dengan judul skripsi "Hubungan Antara Intensitas Bimbingan Muhadhoroh Dengan Kepercayaan Diri Berbicara di Depan Publik Pada Santri Kelas 1 KMI Pondok Pesantren Ta'mirul Islam Surakarta". Skripsi ini meneliti tentang hubungan antara intensitas bimbingan muhadhoroh dengan kepercayaan diri berbicara di depan publik pada santri kelas $1 \mathrm{KMI}$ di Pondok Pesantren Ta'mirul Islam Surakarta. Dan hasil dari penelitian tersebut adalah intesitas mengikuti bimbingan muhadhoroh pada santri kelas 1 KMI Pondok Pesantren Ta'mirul Islam menunjukkan bahwa santri memiliki intensitas mengikuti bimbingan dengan baik yakni dengan presentase yang tinggi sebesar $37,7 \%$, tingkat sedang $57,4 \%$, dan rendah sebesar 4,9\%. Sedangkan tingkat kepercayaan diri santri berbicara didepan publik dikualifikasikan pada tingkat sedang yakni pada tingkat sangat kurang 
$9,80 \%$, tingkat kurang $19,70 \%$, dan sangat baik $8,20 \% .^{5}$

3. Putri Rifa Anggraeni, mahasiswa IAIN Salatiga, NPM 11112009, pada tahun 2016 dengan judul skripsi

"Motivasi Santri Dalam Mengikuti Kegiatan Muhadharah Di Pondok Pesantren Modern Bina Insani Susukan Kabupaten Semarang

Tahun 2016". Skripsi ini meneliti tentang motivasi santri dalam mengikuti kegiatan muhadharah di Pondok Pesantren Modern Bina Insani Susukan Kabupaten Semarang Tahun 2016. Dan hasil penelitian tersebut adalah kegiatan muhadharah wajib dilaksanakn baik kelas 7, 8, dan 10 . Sedangkan kelas 11 berperan sebagai pengurus. Bagi kelas 3 SMP dan kelas 3 SMA mengikuti kegiatan muhadharah hanya sampai semester satu sedangkan pada semester dua dibebaskan tidak mengikuti kegiatan yang ada di pesantren kecuali mengaji. Motivasi bagi santri dalam melaksanakan kegiatan muhadharah adalah dorongan untuk dapat melakukan publik speaking atau berbicara di depan umum. Strategi kegiatan muhadharah adalah suatu penerapan yang diberikan kepad santri untuk memudahkan bagaimana cara melaksanakan dari awal. Sebelum kegiatan muhadhara dilaksanakan, segenap pengurus memberitahukan kepada seluruh santri untuk menyerahkan teks pidato dan intisari sebelum maju ke depan kelas guna mempermudah santri dalam mengahafal teks pidato tersebut. Selain itu untuk meng-efektifkan kegiatan muhadharah pengurus menerapkan pola punish- ment dan reward. Punishment digunakan bagi santri yang tidak hafal, sedangkan reward digunakan bagi santri yang aktif dan lebih unggul dalam penyampaian pidato. ${ }^{6}$

4. Zakiyatun Nisa', mahasiswi UIN Sunan Kalijaga Yogyakarta, NPM 09220013, pada tahun 2013 dengan judul skripsi "Implementasi Program Layana Life Skill Di SMA Muhammadiyah 1 Muntilan". Skripsi ini meneliti tentang implementasi program layana life skill di SMA Muhammadiyah 1 Muntilan. Dan hasil penelitian tersebut adalah program layanan life skill di SMA Muhammadiyah 1 Muntilan ditujukan bagi siswa dalam upaya membantu membekali siswa dengan keterampilan yang bisa membuat mereka lebih mandiri serta menumbuhkan jiwa usaha. Program yang digunakan terdiri dari beberapa bidang keterampilan, yakni keterampilan tangan (handycraft), tata busana, teknisi komputer, teknisi handphone, presenter dan fotogrrafi. Dalam upaya penerapannya yakni pengembangan bakat dan minat siswa dari proggram layanan life skill di SMA Muhammadiyah 1 Muntilan merupakan hal yang diharapkan agar setelah mengikuti kegiatan tersebut, siswa mampu lebih mandiri serta dapat menum-buhkan jiwa usaha dari pengalaman prakteknya. Namun hasil yang diterima setiap siswa tentunya tidak sama, tergantung dari antusian siswa dalam mengikuti kegiatan program layanan life skill di SMA Muham-madiyah 1 Muntilan. ${ }^{7}$ 


\section{Landasan Teori}

\section{Teori Muhadhoroh}

Menurut Eko Setiawan, muhadhoroh adalah suatu rangkaian kegiatan atau proses, dalam rangka mencapai suatu tujuan tertentu. Tujuan ini dimaksudkan untuk memberi arah atau pedoman bagi gerak langkah kegiatan dakwah. ${ }^{8}$

Hadi Rumpoko berpendapat bahwasannya muhadhoroh bisa diartikan sebagai pidato, yakni pengungkapan pemikiran dalam bentuk kata-kata yang ditujukkan kepada orang banyak, atau wacana yang disiapkan untuk diucapkan di khalayak, dengan maksud agar pendengar dari pidato tadi dapat mengetahui, memahami, menerima serta diharapkan bersedia melakasanan segala sesuatu yang telah disampaikan kepada mereka. ${ }^{9}$

\section{Teori Kecakapan Hidup (Life Skill)}

Disamping membutuhkan pengetahuan secara akademik, tentunya yang tidak kalah penting dimiliki oleh peserta didik adalah bekal keterampikan yang relevan dengan lingkungan kehidupannya agar para peserta didik mampu bekerja sesuai dengan keterampilan yang dimilikinya selama mengikuti pendidikan disekolah yang dinamakan sebagai kecakapan hidup atau berbasis life skil. ${ }^{10}$

Brolin mendefinisikan bahwa keca-kapan hidup (life skill) sebagai kontinum pengetahuan dan kemempuan yang diperlukan oleh seseorang untuk berfungsi secara independen dalam kehidupan. Pendapat lain mengatakan bahwa kecakapan hidup adalah kecakapan sehari-hari yang diperlukan oleh seseorang agar dapat meraih kesuksesan di dalam menjalankan kehidupan. $^{11}$

\section{METODOLOGI PENELITIAN}

Berdasarkan latar belakang dan rumusan masalah yang telah dikemukakan diatas, pendekatan yang dilakukan adalah penelitian lapangan (field research) dimana penelitian ini menggunakan pendekatan kualitatif. Penelitian kuaitatif adalah penelitian yang datanya dinyatakan dalam bentuk verbal dan dianalisis tanpa menggunakan teknik statistik. ${ }^{12}$

Penelitian ini bertempat di SMK Muhammadiyah 2 Gresik, yang berlokasi di Jalan Raya klampok no. 21 Benjeng, Kab. Gresik 61172 - Jawa Timur. ${ }^{13}$

Untuk tahap penelitian terdiri atas tahap pra lapangan, tahap pekerjaan lapangan (penggalian data), dan tahap analisis data. ${ }^{14}$

Pada prinsipnya meneliti adalah melakukan pengukuran terhadap fenomena alam maupun sosial. Meneliti dengan data yang sudah ada lebih tepat kalau dinamakan sebagai membuat laporan dari pada melakukan penelitian. Namun demikian dalam skala yang paling rendah laporan juga dapat dinyatakan sebagai bentuk penelitian. $^{15}$ Instrumen dalam penelitian kualitatif adalah peneliti itu sendiri. Peneliti dalam penelitian kualitatif adalah sebagai orang yang membuka kunci, menelaah, dan mengeksplorasi seluruh ruang secara cermat, tertib, dan leluasa. Untuk itu dalam penelitian ini, peneliti menggunakan diri sendiri sebagai instrumen penelitian, bertindak sebagai perencana, pelaksana, pengumpul data, analisis, penafsir data tentang implementasi kegiatan muhadhoroh 
dalam menumbuhkan life skill siswa di SMK Muhammadiyah 2 Gresik.

Penelitian ini adalah jenis penilitian kualitatif dan termasuk dalam jenis penelitian lapangan (field research), yaitu penelitian dengan menggunakan informasi yang diperoleh dari informan atau responden melalui instrumen pengumpulan data seperti dokumentasi, wawancara, observasi, dan lain sebagainya. ${ }^{16}$

Dalam penelitian ini, penulis menggunakan teknik pengambilan data yang meliputi:

Observasi, sebagai teknik pengumpulan data mempunyai ciri yang spesifik bila dibandingkan dengan dengan teknik yang lain, yaitu wawancara dan kuisioner. Wawancara (interview), adalah teknik pengumpulan data yang dilakukan dengan cara bertanya langsung kepada responden atau informan. Dokumentasi, merupakan suatu teknik penngumpulan data dengan menghimpun dan menganalisis dokumendokumen baik dokumen tertulis, gambar maupun elektronik berupa kamera untuk merekam proses pada saat kegiatan penelitian sedang berlangsung. ${ }^{17}$

\section{PEMBAHASAN}

Sekolah ini berdiri sejak tahun 1990 sebagai inisiatif dari warga Muhammadiyah cabang Benjengyang menginginkan adanya sebuah lembaga pendidikan Muhammadiyah yang berorientasi pada bidang kejuruan di wilayah Benjeng. Hal ini dikarenakan pada saat sekolah ini didirikan, jumlah Sekolah Menengah Kejuruan sangat terbatas di wilayah Benjeng dan sekitarnya sedangkan minat masyarakat untuk menyekolahkan anak mereka ke sekolah kejuruan sangat tinggi. 18

Kegiatan muhadhoroh adalah kegiatan pengembangan diri yang wajib untuk diikuti seluruh siswa. Pelaksanaannya dilakukan setiap hari Jumat pukul 07.00 WIB sampai selesai. Kegiatan ini dilakukan secara bergantian oleh perwakilah setiap kelas sesuai jadwal yang telah ditentukan sebelumnya. Berdasarkan observasi yang telah dilakukan oleh peneliti di SMK Muhammadiyah 2 Gresik, bahwasannya sekolah tersebut merupakan sekolah kejuruan yang memegang teguh nilai-nilai Islami sehingga tidak heran apabila SMK Muhammadiyah 2 Gresik berusaha keras untuk menciptakan lulusan-lulusan yang tidak hanya terampil dalam hal kejuruan, namun harus pula terampil dalam berdakwah atau mensyiarkan agama Islam ke khalayak umat dengan cara melaksanakan kegiatan muhadhoroh.

Kecakapan hidup atau life skill adalah kemampuan serta keberanian seseorang untuk menghadapi problem dalam kehidupan dalam hal ini adalah pada saat maju untuk melaksanakan muhadhoroh, kemudian secara kreatif dan proaktif mencari dan menemukan solusi untuk mengatasinya. 19

Dalam mengoptimalkan life skill siswa SMK Muhammadiyah 2 Gresik, tentunya pihak sekolah berupaya semaksimal mungkin untuk mengoptimalisasikan siswa khusunya pada peningkatan keterampilan berdakwah melalui kegiatan muhadhoroh. Dengan bekal kecakapan hidup serta keterampilan yang diperoleh siswa dari setiap jurusan yang dipilih, tentunya masih kurang karena belum terpenuhinya keterampilan di dalam hal komunikasi publik. 
Dalam setiap upaya pengoptimalisasian suatu tujuan, terntunya ada faktor pen-dukung yang membantu untuk menyukses-kan suatu upaya tersebut, selain itu ada pula faktor penghambat yang harus dihadapi guna menuju kesuksesan setiap upaya dan usaha.

Faktor pendukung implementasi kegiatan muhadhoroh dalam menumbuhkan life skill siswa SMK Muhammadiyah2 Gresik adalah: 1) adanya keinginan dari pihak sekolah untuk menciptakan kader-kader Muhammadiyah yang siap berdakwah, 2) adanya motivasi siswa untuk belajar berdakwah, munculnya rasa ingin tahu dan ingin bisa sehigga siswa bersemangat dalam mengikutikegiatan mihahdoroh tersebut, 4) adanya antusias atau simpati dari siswa dalam pelaksanaan kegiatan muhadhoroh.

Sementara itu faktor penghambat yang ditemui dalam implementasi kegiatan muhadhoroh dalam menumbuhkan life skill siswa adalah: 1) rendahnya motivasi beberapa siswa untuk belajar dan mengikuti kegiatan muhadhoroh, 2) adanya rasa malu dan kurang percaya diri apabila ditunjuk menjadi pengisi atau petugas muhadhoroh, 3) kurangnya persiapan dari siswa sehingga pada saat tampil hanya sekedar tampil dan terkesan asal-asalan, 4) adanya beberapa anak petugas muhadhoroh yang tidak masuk pada saat pelaksanaan kegiatan muhadhoroh.

Kegiatan muhadhoroh ini memang sangat bergantung pada motivasi dari masing-masing siswa serta bakat yang memang telah mereka miliki sebelumnya, sehingga tidak heran apabila terdapat beberapa siswa yang terkesan asal-asalan apabila ditunjuk sebagai petugas muhadhoroh.

\section{SIMPULAN}

Berdasarkan pembahasan pada bab sebelumnya dapat diketahui bahwasannya implementasi kegiatan muhadhoroh di SMK Muhammadiyah 2 Gresik sudah cukup baik, namun perlu digaris bawahi bahwa penumbuhan life skill di sekolah ini melalui kegiatan muhadhoroh masih belum merata karena masih adanya beberapa siswa yang tidak memiliki motivasi berlebiha sehingga terkesan hanya asal-asalan saja dalam melaksanakan kegiatan muhadhoroh ter-sebut. Namun ada juga beberapa siswa yang memang memiliki bakat serta motivasi tinggi dalam melaksanakan kegiatan muha-dhoroh sehingga kemampuannya semakin ditingkatkan melalui kegiatan tersebut.

Faktor pendukung dari kegiatan muhadhoroh di SMK Muhammadiya 2 Gresik adalah; 1) adanya keinginan dari pihak sekolah untuk menciptakan kader-kader Muhammadiyah yang siap berdakwah.

2) adanya motivasi siswa untuk belajar berdakwah melaui kegiatan muhadhoroh. 3) munculnya rasa ingin tahu dan ingin bisa sehigga siswa bersemangat dalam mengikutikegiatan mihahdoroh tersebut. 4) adanya antusias atau simpati dari siswa dalam pelaksanaan kegiatan muhadhoroh. Sementara itu faktor penghambat kegiatan muhadhoroh di SMK Muhammadiyah 2 Gresik adalah; 1) rendahnya motivasi beberapa siswa untuk belajar dan mengikuti kegiatan muhadhoroh. 2) adanya rasa malu dan kurang percaya diri apabila ditunjuk menjadi pengisi atau petugas muhadhoroh.

3) kurangnya persiapan dari siswa sehingga pada saat tampil hanya sekedar tampil dan terkesan asal-asalan. 4) adanya beberapa anak petugas muhadhoroh yang tidak masuk 
pada saat pelaksanaan kegiatan muhadhoroh.

\section{Daftar Rujukan}

, Pedoman Penulisan Proposal \& Skripsi, Gresik: FAI UMG, 2017.

Anggraeni, Putri Rifa, Motivasi Santri

Dalam Mengikuti Kegiatan

Muhadharah Di Pondok Pesantren

Modern Bina Insani Susukan

Kabupaten Semarang Tahun 2016,

Skripsi, Jurusan Pendidikan Agama

Islam Fakultas Tarbiyah Dan Ilmu

Keguruan IAIN Salatiga, 2016.

Departemen Agama Islam, Pedoman Pendidikan Kecakap Hidup (Life Skill) dalam Pembelajaran, Jakarta: Depag, 2005.

Nata, Abuddin, Metodologi Studi Islam, Jakarta: Raja Grafindo Persada, 2002.

Nazir. M, Metode Penelitian, Jakarta: Ghalia Indonesia, 1988.

Nisa, Zakiyatun, Implementasi Program Layana Life Skill Di SMA Muhammadiyah 1 Muntilan,Skripsi, Jurusan Bimbingan Dan Konseling Islam Fakultas Dakwah Dan Komunikasi UIN Sunan Kalijaga Yogyakarta, 2013.

Nurdin, Ali, "Pendidikan Life Skill Dalam menumbuhkan Kewirausahaan Pada Peserta Didik Pendidikan Non Formal Paket C", Jurnal Tarbawi Volume 2 No. 02, Juli-November 2016.

Oktari, Fima Riska, Strategi Pelatihan Muhadharah Terhadap Kemampuan Berpidato Santri Pondok Pesantren Darul Falah Teluk Betung Bandar
Lampung, Skripsi, Fakulsas Dakwah dan Ilmu Komunikasi UIN Raden Intan Lampung, 2017.

Pesan Singkat dengan Ibu Ratri Suraswati, S.Pd selaku Waka Kurikulum SMK Muhammadiyah 2 Gresik, 13 Februari 2018, pukul 19:40 WIB.

Rachman, Hari Amirullah, "Dimensi Kecakapan Hidup (Life Skill) Dalam Pembelajaran Pendidikan Jasmani”, Jurnal Pendidikan Jasmani Indonesia, Volume 6, No. 2, November 2009.

Rahman, Dian Faishal, Hubungan Antara Intensitas Bimbingan Muhadhoroh Dengan Kepercayaan Diri Berbicara di Depan Publik Pada Santri Kelas 1 KMI Pondok Pesantren Ta'mirul Islam Surakarta, Skripsi, Jurusan Pendidikan Agama Islam Fakultas Tarbiyah dan Ilmu Keguruan IAIN Salatiga, 2016.

Rumpoko, Hadi, Panduan Pidato Luar Biasa, Yogyakarta: Megabooks, 2012.

Samsul, Romli, Jurnalistik Dakwah, Bandung: Rosda Karya, 2003.

Setiawan, Eko, "Strategi Muhadharah Sebagai Metode Pelatihan Dakwah Bagi Kader Da'i Di Pesantren Daarul Fikri Malang” , Jurnal Fenomena, vol. 14 No.2, Oktoer 2015.

smkmuda2gres.blogspot.co.id, diakses pada tanggal 11 Mei 2018, Pukul 17.02 WIB.

Sugiyono, Metode Penelitian Kuantitatif, Kualitatif, dan $R \& D$, Bandung: Alfabeta, 2016.

Syaodah Sukmadinata, Nana, Metode Penelitian Pendidikan, Bandung: Remaja Karya, 2009. 


\section{Tim, Edisi Revisi, Dasar-Dasar Metodologi}

Penelitian, Malang: Universitas Negeri

Malang, 2003.

\footnotetext{
${ }^{1}$ Romli Samsul, Jurnalistik Dakwah, (Bandung: Rosda Karya, 2003), hal. 3.

${ }^{2}$ Eko Setiawan, "Strategi Muhadharah Sebagai Metode Pelatihan Dakwah Bagi Kader Da’i Di Pesantren Daarul
} Fikri Malang”, Jurnal FENOMENA, Vol. 14 No. 2 (Oktober 2015), hal. 307.

${ }^{3}$ Pedoman Penulisan Proposal \& Skripsi, (Gresik: FAI UMG, 2017), hal.7.

${ }^{4}$ Fima Riska Oktari, Strategi Pelatihan Muhadharah Terhadap Kemampuan Berpidato Santri Pondok Pesantren Darul Falah Teluk Betung Bandar Lampung, Skripsi, Fakulsas Dakwah dan Ilmu Komunikasi UIN Raden Intan Lampung, 2017.

5 Dian Faishal Rahman, Hubungan Antara Intensitas Bimbingan Muhadhoroh Dengan Kepercayaan Diri Berbicara di Depan Publik Pada Santri Kelas 1 KMI Pondok Pesantren Ta'mirul Islam Surakarta, Skripsi, Jurusan Pendidikan Agama Islam Fakultas Tarbiyah dan Ilmu Keguruan IAIN Salatiga, 2016.

${ }^{6}$ Putri Rifa Anggraeni, Motivasi Santri Dalam Mengikuti Kegiatan Muhadharah Di Pondok Pesantren Modern Bina Insani Susukan Kabupaten Semarang Tahun 2016, Skripsi, Jurusan Pendidikan Agama Islam Fakultas Tarbiyah Dan Ilmu Keguruan IAIN Salatiga, 2016.

${ }^{7}$ Zakiyatun Nisa, Implementasi Program Layana Life Skill Di SMA Muhammadiyah 1 Muntilan, Skripsi, Jurusan Bimbingan Dan Konseling Islam Fakultas Dakwah Dan Komunikasi UIN Sunan Kalijaga Yogyakarta, 2013.

${ }^{8}$ Eko Setiawan, Op. Cit., hal. 307.

${ }^{9}$ Hadi Rumpoko, Panduan Pidato Luar Biasa, (Yogyakarta: Megabooks, 2012), hal. 12

${ }^{10}$ Ali Nurdin, "Pendidikan Life Skill Dalam menumbuhkan Kewirausahaan Pada Peserta Didik Pendidikan Non Formal Paket C”, Jurnal Tarbawi Volume 2 No. 02, (Juli-November 2016), hal. 110.

${ }^{11}$ Hari Amirullah Rachman, "Dimensi Kecakapan Hidup (Life Skill) Dalam Pembelajaran Pendidikan Jasmani", Jurnal Pendidikan Jasmani Indonesia, Volume 6, No. 2, (November 2009), hal. 20.

${ }^{12}$ Tim, Edisi Revisi, Dasar-Dasar Metodologi Penelitian, (Malang: Universitas Negeri Malang, 2003), hal. 8.

${ }^{13}$ Pesan Singkat dengan Ibu Ratri Suraswati, S.Pd selaku Waka Kurikulum SMK Muhammadiyah 2 Gresik, 13 Februari 2018, pukul 19:40 WIB.

${ }^{14}$ M. Nazir, Metode Penelitian, (Jakarta: Ghalia Indonesia, 1988). hal. 127.

${ }^{15}$ Sugiyono, Metode Penelitian Kuantitatif, Kualitatif, dan R\&D, (Bandung: Alfabeta, 2016), hal. 102.

${ }^{16}$ Abuddin Nata, Metodologi Studi Islam, (Jakarta: Raja Grafindo Persada, 2002), hal. 125.

${ }^{17}$ Nana, Syaodah Sukmadinata, Metode Penelitian Pendidikan, (Bandung: Remaja Karya, 2009), hal. 221.

${ }^{18}$ smkmuda2gres.blogspot.co.id, diakses pada tanggal 11 Mei 2018, Pukul 17.02 WIB.

${ }^{19}$ Departemen Agama Islam, Op., Cit, hal.5 
Jurnal TAMADDUN - FAI UMG. Vol. XIX. No.1 / Januari 2018 